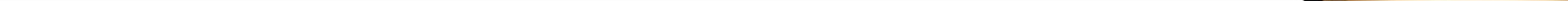




\section{Mulholland Drive: An Intertextual Reading}

\section{Ebrahim Barzegar}

The origin of intertextuality lies in the theories and philosophies of the key figure of Russian Formalist School Mikhail Bakhtin whose works were unknown to literary critics due to the political censorship and social oppression of his time. Bakhtin found a new alternative to Saussaurian theory of language by stressing the overlooked fact of his language theory, the social aspect. For Bakhtin, the social situation of language users plays a crucial part in shaping the parole of the given language system; in better words, "language exists in social situations between actual speakers" (Allen, 2003, p.80). In Marxism and Philosophy of Language Bakhtin emphasized that ignoring the sociological perspective of language led to 'abstract objectivism' as Saussure did. In contrast to Saussure's viewpoint, meaning, for Bakhtin, is the product of interaction of particular individuals within the particular social situations; therefore, constant dialogue lies at the heart of Bakhtin's thinking.

In his Problems of Dostoevsky's Poetics (1929), he introduced his concept of dialogism and heteroglossia in the work of Fyodor Dostoevsky but his concept received its fullest treatment in his locus classicus essay Discourse in the Novel in 1934. Dialogism means the coexistence of two voices in one. As an antidote to monologism, it is gained in two ways: first by the juxtaposition of numerous voices of given text; and second by the text's combination of formerly textual or cultural discourse; therefore, the central tradition of the novel is constituted by texts which are not unitary in their discourse ('monological') but multiple, polyphonic ('dialogic')" (Rimmon-Kenan 2002, p.119). Unlike the objective and authorial voice of an epic or a lyric, Bakhtin proposed that novel represents a multi-voiced utterances or discourses including character' world view, ideology or social status. To Bakhtin, as Allen remarked "All utterance are dialogic, their meaning and logic dependent upon what previously been said and 
on how they will be received by others" (2000, p.19). As a result, one can perceive that there exists an otherness in his/her utterance; more than one voice is present within his/her utterance. This utterance could occur either at the level of phrase or collection of works. This sense of otherness in Bakhtin's word is called Heteroglossia.

Originally derived from a Greek language, heteroglossia is a combination of hetero and glot which former means other and the latter means language. Central to Bakhtin's theory of the novel is his belief that living language displays heteroglossia. It is frequently used to describe the simultaneous existence of various voices within a single language. To put it another way, heteroglossia is the "language's ability to contain within it many voices, one's own and other voices". As Bakhtin wrote in Discourse of the Novel:

at any given moment of its historical existence, language is heteroglot from top to bottom: it represents the co-existence of socio-ideological contradictions between the present and the past, between differing epochs of the past, between different socio-ideological groups in the present, between tendencies, schools, circles and so forth, all given a bodily form. These 'languages' of heteroglossia intersect each other in a variety of ways, forming new typifying 'languages'. (1989, p. 676)

Setting in opposition to monoglossia and its unifying feature, not only heteroglossia displays the centrifugal forces of language but also shows the social stratification of the language. Language became a magnetic field for diverse voices: "social dialects, characteristic group behavior, professional jargons, generic languages, languages of generations and age groups, tendentious languages, languages of the authorities, of various circles and of passing fashions, languages that serve the specific sociopolitical purposes of the day, even of the hour" (ibid.p.674). One should keep in mind that the speech of a single character within the novel 
also contains heteroglot quality, as Bakhtin put it: "It serves two speakers at the same time and expresses simultaneously two different intentions: the direct intention of the character who is speaking, and the refracted intention of the author" (1981, p.323).

From Bakhtin's standpoint, each novel is constructed from a diversity of styles and voices, assembled into a structured artistic system, which arranges difference in a particular way. This very diversity of styles and voices within a text attracted Kristeva and paved her way to transform dialogism of Bakhtin into a new term in literary criticism, Intertextuality.

Kristeva's concept of intertextuality initially appeared in one of her book' article Word, Dialogue, Novel in1966 where she introduced the Russian thinker Bakhtin to the French public and two years later, it fully developed in another article named The Bounded Text.

Kristeva's development of the notion of intertextuality is indebted to the works of Mikhail Bakhtin. Graham Allen reiterated the extreme importance of Bakhtin's work in forming Kristeva's concept as:

Not only does Kristeva coin the term intertextuality, but in doing so she introduces a figure [i.e. Bakhtin] who has since been styled the most important literary theorist of the twentieth century. Intertextuality and the work of Bakhtin are not, that is to say, separable, and in understanding the former we clearly must understand something of the latter. (2000, p.15)

What Allen means as 'something of the latter' is Bakhtin's work on the 'double-voiced' discourse or dialogism.

Bakhtin declares that there is not any single utterance whose meaning is independent of other utterances. The meaning of each utterance or discourse is appropriated from its relations to others. This otherness is termed polyphony or heteroglossia. What the 'polyphonic' novel denotes is well revealed in Bakhtin's assessment of Dostoevsky's novels. He writes: 
A plurality of independent and unmerged voices and consciousnesses, a genuine polyphony of fully valid voices is in fact the chief characteristic of Dostoevsky's novels. (1984, p.5)

Since the text displays the plurality of voices, author's voice is no longer superior to any other character's voices; in other words, there is no dominant voice or any kind of monologism.

Following Bakhtin's concept of dialogism, Kristeva proposed her own term with some alterations. Kristeva in his process of making a new term made two crucial changes. First, whereas Bakhtin's work stressed on the actual human subject, Kristeva focused on the text and textually. Second, wherever she used the 'poetic language' in her discussion about literary language, it bears no resemblance to Bakhtin's idea about poetry. In fact what she meant is that literary word is "an intersection of textual surfaces rather than a point (a fixed meaning), a dialogue among several writings; that of the writer, the addressee (or the character), and the contemporary or earlier cultural context" (Kristeva 1980, p.65). Thus every dialogue is the a rich intersection of an inside and outside voices or texts. This combination of voices and texts lead to the redescription of Bakhtin's theory of dialogism and coinage of the term intertextuality "Any text is constructed as a mosaic of quotations; any text is the absorption and transformation of another" (ibid. p. 66).

In asserting that a text is not self-contained but related to other texts from which this text derives, however, intertextuality does not tend to assert meanings based on the 'intertextual' relations as the term literally denotes. Instead, intertextuality attempts to devalue and undermine these relations. Through 'signifying systems', intertextuality dissolves the possibility of establishing a stable meaning, arguing that the text is much too heterogeneous to 
be interpreted determinately. Therefore, a literary work is not simply the product of a single author, but of its relationship to other texts.

Lynch's films are dense with allusions and intertexts. These apparent meanings are not the only ones which make them fascinating. As work of cinema, Mulholland Drive takes on the pre-existent films, genres or traditions and attempts to critically respond to notion of intertextuality in postmodern trend. Lynch viewers have to consider the network of textual relations besides their significance in order to grasp the depth of the meaning of the film; therefore, this section focuses on the network of intertexts from film noir genre particularly Sunset Boulevard (Billy Wilder, 1950), The Wizard of Oz (Victor Fleming, 1939), Persona (Ingmar Bergman, 1966), to Lynch's earlier films.

In postmodern trend an author is allowed to borrow and imitate freely from other texts without any specific concern for the original text and its author. This form of textual recycling underlines the fact that the meaning of a text depends on the used works along with the new context it is located. Since Lynch is an American director his influence by his forefather's directors and their genres in cinematic world is substantial, particularly film noir.

Robert Profirio in the preface to The Philosophy of the Film Noir mentioned themes such as murder, revenge, betrayal, and temptation as the mainstays of film noir genre (2006, p. x). Lynch in Mulholland Drive which stress these points. The first one happens in Aunt Ruth's apartment in form of phony dialogues between Betty and Rita in whom the former plays the corrupted innocent while the latter is the experienced seducer.

Betty: My parents are right upstairs. They think you've left.

Rita: So, surprise? 
Betty: If you're trying to blackmail me, it's not gonna work. You are playing a dangerous game here.

Rita: You know what I want. It's not that difficult.

Betty: Get out before I call my dad. He trusts you. You're his best friend. $(1: 16: 42-1: 16: 46)^{1}$

These remarks refer the hard-boiled dialogue of a couple in American film noir of 1940s. While this scene is acted in a light-hearted manner, the next scene which occurs in Diane's apartment suggests the intensity of the situation. Half-clothed, Diane plays the seducer and Camilla the femme fatale role in a real part of the film in a flashback scene.

Diane: What was that you were saying, beautiful?

Camilla: I said, 'You drive me wild'...we shouldn't do this anymore.

Diane: Don't say that. Don't ever say that.

Camilla: Don’t Diane. Stop it. I tried to tell you this before.

Diane: It's him, isn't it? (2:02:04-2:03:00)

The blunt refusal of Camilla to Diane's request stresses the underlying noirish theme of treachery; moreover, it evokes the stereotypical mood and imagery of the ruthless femme fatal figure that is the ultimate object of desire male protagonist. It is important to notice that Lynch augments the tone of betrayal by depicting the lesbian affair, for it exhibits, as Heather Love

\footnotetext{
${ }^{1}$ Since the film script is not available, the reference to the scene is given in time
} 
points out, the "structural effect of homophobia" in the mainstream of Hollywood cinema. Camilla's decision to abandon her female lover for male one, Adam Kesher over Diane, not only shares the betrayal theme of noir genre but also depicts the modern "tragedy of an individual lesbian relationship in the homophobic society" (Love, 2004, p. 130). Following her rejection by Camilla, Diane embarks to avenge her love by hiring a hitman to kill her; therefore, her actions embrace the other two themes of noir genre.

Lost Highway, a psychological thriller film, also framed around film noir plot. Alice, the blonde seductress partner of Mr. Eddy, tries to persuade Pete to murder him and runaway together. Conversing in a hotel room, Alice proposed her scheme to Pete as following,

I know a guy. He pays girls to party with him. He has a lot of cash. He'd be easy to rob. Then we'd have the money. We could go away. We could be together. (1:28:451:29:51)

These lines clearly depict the common film noir plot of murder, moral dilemma, money and betrayal. Lynch's alluding to noir style also represented in physical appearance of Alice. In the second part of the film, Alice's appearance at Andy's house fits the archetypal femme fatale who "dressed in her underclothes and holding a gun with which she playfully threatens Pete" (MacTaggart, 2010, p. 40).

Femme fatales are the common figures in Lynch's films. Dorothy Valens in Blue Velvet is another instance of femme fatale in Lynch's oeuvre. Jeffery Beaumont plays a naïve detective who is curious to solve Dorothy's problem, but is allured to victim. Finding Jeffery in her closet, Dorothy threatens and tempts him with a knife to have sex with her. Lynch's first feature film, Eraserhead, also depicts the femme fatale in the character of the beautiful Girl across the Hall. The image of blonde Laura Palmer in Twin Peaks series is another example of 
"femme fatale and damsel in distress" because it made FBI detective Dale Cooper to accept her "invitation to danger and love" and above all to risk his life to solve her case (Olson, 2008, p. 292). Moreover, as Jason Holt mentioned the jazz sound track, trench-coated private investigator and the underlying criminal world in Twin Peaks clearly show the noir influence in series (2008, p. 249).

In his autobiographical book, Lynch said that "I am a huge admirer of Billy Wilder. There are two films of his that I most love about because they create such a world of their own: Sunset Boulevard and The Apartment" (2006, p. 141). Mulholland Drive could be considered as his great tribute to Wilder's Sunset Boulevard because there are several moments, which he explicitly and implicitly refers to this film.

Christian Metz, the renowned film semiotician, divides cinematic language signs into five tracks; one of them is the 'writing', which includes credits and written materials (2005, p. 38). The first 'written material' is the title on the film poster. Lynch portrays the title of the film in the abbreviation form Mulholland Dr. much the same way as Wilder's Sunset Blvd. title. Lynch emphasizes his reference in a clear shot when his camera focuses on the street sign written on it Sunset Blvd. In another shot of the film, Lynch's camera shows Winkie's restaurant tableau with the subtitle of Sunset Blvd. and police siren sound. The visual image and audial sound both alludes the police siren sound into the opening scene of Wilder's film that are heading to crime scene at Norma Desmond's apartment.

Besides the written form allusion, the setting of the film is also refers to Wilder's film. Betty's entrance to the courtyard of Norma's Spanish-Mediterranean mansion bears a strong resemblance to Joe's arrival to the similar mansion in Sunset Boulevard where she "penetrates into an inner space of secrets and desires" of noirish setting (Olson, 2008, p. 352). Betty's 
entrance to her Aunt Ruth's house in a microcosmic scale depicts Hollywood's world because her artistic and romantic life is threatened by Hollywood's mafia and Rita and her lovers, respectively.

Joe Gilles winds up at Norma's ghostly mansion after his car broke down on a highway above the Los Angeles. In a fairly similar pattern, 'Driving down a parallel track, the Mulholland Drive woman's accident allows her to escape her two male assailants, find her way to a classic Spanish Colonial courtyard apartment that will be a locus of intense feelings, and introduce her to her primal partner in Lynch's tale.' The surviving woman then made her way down to Hollywood's residential blocks where the signs for Franklin Avenue (a cross-street of William Holden's Sunset Boulevard apartment), and Sunset itself are displayed (Olson, 208, p. 528-529).

Lynch's depiction of his film protagonist recalls Sunset Boulevard's female lead character. Norma and Diane share similar narcissism, in other words, they are living in their own dream world where reality and fantasy go hand in hand together. In their fantasy they see themselves as a successful superstar with prosperous future but in reality they are nothing but losers. Moreover, Both Norma and Diane displayed violent and psychotic obsession toward their lovers, Joe and Camille that finally led them to perpetrate murder; "Like Norma Desmond in Sunset Boulevard, Diane will stop the person she loves from escaping her with a hail of .45caliber forget-me-nots" (Olson, 2008, p. 574). In contrast to the murder of Joe by Norma, Diane hired a hitman to do the job for her. The trauma of the shooting pushes Norma over the edge into mental collapse, and when reporters and newsreel cameras arrive at the house, she imagines that they are there as part of her new film project Salome whereas Diane's 'desperate plunge into her dream which enfolded her'(Joe's sentence in Sunset Boulevard) made her to commit suicide. 
In others Lynch's film one can detect the cinematic allusions to others film noir's work of art. Take Lost Highway for example. From Naremore's point of view, Lost Highway “brims with allusions to three decades of noir, which it uses to create a dream narrative" (2008, p. 273). He adds that:

Almost every image and every character in the film has an archetypal quality: a nocturnal road out of Detour and Psycho; a "Lost Highway Motel," where a woman may or may not be dead; an exploding house on stilts like the one in Kiss Me Deadly; an alienated jazz musician who might be a killer; a brooding rebel-without-a-cause who lusts after a gun moll; a sadistic gangster who is obsessed with porn movies and prostitutes; a woman's mutilated body, reminiscent of the Black Dahlia; and not one but two femmes fatales - the first a redhead like Gilda, the second a blond like Phyllis Dietrichs. (ibid.)

Besides Naremore's allusions, the following references are important to be noticed in relation to the concept of intertextuality. Dick Laurent's porno rings alludes to The Big Sleep; the frantically snaking roads evoke Detour (Edgar G. Ulmer, 1945); and the most significantly flaming, imploding cabin is strongly reminiscent of Kiss Me Deadly (Robert Aldrich, 1955). Thus, by embracing various themes and references to film noir, Lost Highway "remains frozen in a kind of cinématheque and is just another movie about movies" (ibid, p. 275).

Blue Velvet is likewise alludes to film noir elements. Jeffery Beaumont's character role as a naïve detective brings to mind Sam Spade (Humphrey Bogart) in The Maltese Falcon (John Huston, 1941) or Jay Gittes (Jack Nicolson) in Chinatown (Roman Polanski, 1974). The breaking and entering scene of Dorothy's apartment, according to Devin Costello, alludes to 
The Prowler (Joseph Losey, 1951) film noir, since in both films the detectives end up sleeping with the women (2010, p.127).

Further instance of intertextuality in Mulholland Drive include allusion to The Wizard of $\mathrm{Oz}$ (Victor Fleming, 1939), which maps major portions of his artistic territory in theme of journey, fantasy and illusion. As far as theme of journey's concerned, Dorothy and Betty begin their dream journey with yellow brick and yellow cab, respectively. The images of the curvy road and the highway with its continual yellow lines connote the journey through the yellow brick road in Oz. whereas the theme of journey and road are "spaces of reunion ....and community and communication" in Wild at Heart and The Straight Story, In Mulholland Drive and Lost Highway are "equated with the psychological travel" of protagonists, Diane and Fred, into a "dream/fantasy state" (Orgeron, 2002, p. 34).

Dorothy's fantasy is similar to Diane's one in the first part of the film. In Diane's fantasy, Rita is in need of part of his brain, memory, Adam Kesher should be courageous to face the mafia gangster, and Betty is looking for her love, heart. These three characters parallel the Scarecrow, Cowardly Lion and Tin Woodman respectively. Moreover, the malevolent and wicked Mr. Roque (played by Michael Anderson, also appeared in Twin Peaks) with his diminutive physical size calls to mind the character named Roquat, described as the Nome (Gnome) King, ruler of the underground world who is about 4 feet tall. At the end of the film, Diane is invited to a party at a hillside state where all her fantasy characters are appeared to have other identities. Her fantasy world is analogous to Dorothy's fantasy dream, for her world was filled characters in disguise. Regarding this idea, Orgeron states that "It is not until after she regains consciousness at film's end that she realizes that her adventures were peopled with her own family and community, the familiar in disguise" (2002, p. 32). 
The same is true for Diane's fantasy world because every character has different identities in real world. Coco, the neighbor in the first part, is mother of Adam Kesher, Rita is Camilla in reality, Adam Kesher is a successful director unlike the first part and Betty is Diane. Mulholland Drive and Lost Highway are similar in the theme of fantasy. In the second part of the film Fred and Renee are transformed into Pete and Alice.

In addition to fantasy, illusion is of crucial issue in Mulholland Drive. Having gone through a great deal of hardship, Dorothy finally met The Great Wizard of the $\mathrm{Oz}$, which turned out to be an illusion constructed by machine behind the curtain. Lynch made a parallel story in Club Silencio. In the mysterious Club Silencio, the Magician constantly reminds the audiences in Spanish, French and English that what you see is an illusion and in a puff of smoke fades away as did Oz. While Dorothy finally discovers the man who runs the show in Oz, Betty and Rita, as well as viewers, are uncertain who did the illusion in Lynchland.

Blue Velvet and Wild at Heart likewise display some themes of The Wizard of Oz. Jeffery Beaumont in his Oedipal journey in Blue Velvet met Frank Booth who in split-second jumps from the scene in the room to the road as "People come and go so quickly" in the Oz (Olson, 2008, p. 242).In Wild at Heart, Lynch explicitly refers to the story of Dorothy and the Bad and Good witch. Marietta like the evil Wicked Witch with the long blood-red nails gestures across the face of an opaque crystal ball and controls Lula' life. In another instance, Lula, in her mind's eye, sees an image of the fearsome Marietta in full witch's regalia riding a broomstick just like Margaret Hamilton's Wicked Witch does in The Wizard of $O z$ (ibid. p. 318). And the film ends with what Arp and Brace described as "a fantastical deus ex machina, Glinda the Good Witch (played by none other than Laura Palmer herself, Sheryl Lee) arrives in her bubble to counter Sailor's false conclusion with her contention that Lula loves him and that's all that matters" (Arp 
\& Brace, 2011, p. 22). The allusion to the Wizard of the Oz, McGowan argues, is that 'Lynch depicts worlds of desire by absence of the object" (McGowen, 2007, p.19).

Reading Lynch through a Bergmaneque filter will contribute to an expanded understanding of Lynch's aesthetics and intertext. Lynch's intertextual domain is not limited to just American cinema. Persona is a psychological drama revolving around the relationship between two women, Elizabeth Vogler and Alma. The former is a successful actress who is hospitalized for a nervous breakdown with symptoms of 'muteness and a near catatonic lassitude' and the latter is the pretty young nurse who is in charge of her care. These two characters through some mysterious process exchange identities (Michaels, 2000, p. 65). Similar characters are presented in Mulholland Drive, an amnesiac brunet and an aspirational blonde with shifting identities. In his analysis of the relationship of the two main women in Persona, Steve Vineberg argues that Bergman displayed the mysterious identities of his characters in two ways. The first is through the mirror exercise where the initiator and responding character is almost impossible to pin down and the second one is the metamorphosis, a process of transformation of the characters. The idea of flux identity is similarly expressed in Lynch's film. The wounded and traumatized brunet who is unable to remember anything including her name, after taking shower picked up a name, Rita, from the poster of Rita Hayworth on the bathroom wall through the mirror shot. Later in the film, Betty put on a blonde wig on Rita's head in front of the bathroom's mirror and then said "You look like someone else"(1:37:42). It seems that Betty perpetually provides identity for Rita and she passively adopts it. The question of identity reaches its climax after the lovemaking of Rita and Betty in Bed. 
Lynch is the master of combination of opposite forces and mixed identity within a single shot. After lovemaking scene of Rita and Betty, "Lynch films their horizontal visages from a certain angle, so that their two faces seem to from a single face: the woman of light and the woman of darkness conjoined in love" (Olson, 208, p. 558). It explicitly refers to the "unforgettable mirror shot in which the two women's faces merge; an image of metamorphosis" (Michaels, 2000, p. 124).

Lynch simply uses intertextual elements to put the notion of originality question. In this case, the viewers are able to study and judge the film as a text. The text from this point of view is like a web, a network of discourses. These discourses are highlighted in the innumerable references to other films such as Sunset Boulevard, The Wizard of $\mathrm{Oz}$ and Persona. Lynch through the concept of intertextuality reminds his viewers that meaning is not only inherent in his film, but is also imposed on it by the already made films.

\section{BIBLIOGRAPHY}

Allen, Graham. Intertextuality. New York: Routledge, 2000.

Roland Barthes. London: Routledge Critical Thinkers, 2003.

Bakhtin, Mikhail. "Discourse in the Novel." Rivkin, Julia and Michael Ryan. Literary Theory: An Anthology. Lodon: Blackwell, 1998. 674-685.

Problems of Dostoyevsky's Poetics. Trans. Caryl Emerson. Minneapolis: University of Minnesota Press, 1984.

The Dialogic Imagination: Four Essays. Ed. Michael Holquist. Trans. Michael Holquist and Caryl Emerson. Austin: University of Texas, 1981.

Conrad, T. Mark. The Philosophy of Film Noir. Kentucky: The University of Kentucky, 2006. 
Costello, Devin. "Fantasy, Desire and The Surrel: Defamiliarizing The American Dream Through Blue Velvet." Cultural Landscapes (2010): 109-131.

Devlin, William J. and Shai Biderman. The Philosophy of David Lynch.. Kentucky: The University Press of Kentucky, 2011.

Holt, Jason. "Twin Peaks, Noir, And Open Interpretation." The Philosophy of TV Noir. Ed. Steven M. Sanders and Aeon J. Skoble. Kentucky: The University Press of Kentucky, 2008.

Kristeva, Julia. Desire in Language: A Semiotics Appraoch to Literature and Art. Ed. Leon S. Roudiez. Trans. Thomas Gora, Alice Jardine and Leon S. Roudiez. New York: Columbia University Press, 1980.

"Word, Dialogue, Novel." The Kristeva Reader. Ed. Toril Moi. Oxford, 1986.

Love, Heather K. "Spectacular Failure: The Figure of the Lesbian in Mulholland Drive." New Literary History I.35 (2004): 117-32.

Lynch, David. Catching the Big Fish: Meditation, Consciousness, and Creativity. New York: Penguin, 2006.

Mactaggart, Allister. The Film Paintings of David Lynch: Challenging Film Theory. Bristol \& Chicago: Intellect, 2010.

McGowan, Todd. The Impossible David Lynch. New York: Columbia University Press, 2007.

Michaels, Lloyd. Ingmar Bergman's Persona. Cambridge: Cambridge Film Handbooks, 2000.

Naremore, James. More Than Night:Film Noir In Its Contexts. California: University of California, 2008.

Olson, Greg. Beautiful Darkness. Toronto: Scarecrow Press, 2008.

Orgeron, Devin. "Revising the Postmodern American Road Movies: David Lynch's The Straight Story." Journal of Film and Videro 54 (2002): 31-46.

Rimmon-Kenan, Shlomith. Narrative Fiction. London: Routledge, 2002. 
Stam, Robert, Robert Burgoyne and Sandy Flitterman-Lewis. New Vocabularies in Film Semiotics: Structuralism, Post-structuralism and Beyond. London \& New York: Routledge, 2005 . 